Kaleidoscope

\title{
Krónikus vesebetegség múltja, jelene és jövőbeli lehetőségei a multidiszciplináris gyógyítás fényében
}

\section{Past, present and future possibilities of chronic kidney disease in multi-disciplinary terms}

\author{
Mátyás Eszter, doktoranda \\ Semmelweis Egyetem Elméleti és Transzlációs Orvostudományok Doktori Iskola \\ matyas.eszter@phd.semmelweis.hu
}

Initially submitted March 1, 2021; accepted for publication March.29, 2021

\begin{abstract}
Since the early treatment of kidney diseases, there have been significant achievements in medical technology. In the middle of the last century, serious ethical considerations surrounded the selection of patients suitable for dialysis, however, all patients who need it today can receive dialysis in all developed countries. Focusing on biological factors, psychosocial support for patients has been relegated in modern medicine. End-stage renal diseases lead to crisis situations, various treatments of kidney replacements contribute to a significant mental burden with a serious impact on the patients' social activities. Due to the simple and tangible features of the peer support mediating knowledge, behavioural patterns and societal values - albeit informally - it was always present with its evidence-based positive effects. Nevertheless, until recently, only a few programs have been developed with a focus on peer support.
\end{abstract}

Kulcsszavak: krónikus vesebetegség, dialízis, kortárstámogatás

Keywords: chronic kidney disease, dialysis, peer support

\section{Bevezetés}

„Sokat vagyunk együtt, mégis elpusztít minket a társas magány.” Az idézet Albert Schweitzer német teológus, orvos, író tollából származik - ez azonban akár egy hemodialízisben részesülő krónikus vesebeteg gondolata is lehetne hazánkban most, a 21. században.

A fejlett országokban az átlagos életkor emelkedésével nő a krónikus betegségek prevalenciája, ami az orvosi technológia fejlődése ellenére számos társadalmi és gazdasági kérdést vet fel. A krónikus megbetegedések közül a krónikus veseelégtelenségben szenvedők helyzete igen komplex problémát jelent. Mind a betegség tünetei, mind a kezelés sajátosságai nagymértékben korlátozzák a páciensek mindennapi életvitelét, életük számos területére befolyást gyakorolva (Yach, Hawkes, Gould és Hofman, 2004).

\section{Vissza az időben}

Az első dialízis Georg Haas (1886-1971) német orvos nevéhez füződik, melyet 1920-ben Gießenben végzett (Haas, 1928). A klinikai dialízis bevezetése Willem Johan Kolff, Nils Alwall, Leonard Tucker Skeggs és Jack Leonards munkássága által valósult meg.

A második világháború idején, 1944-ben Willem Johan Kolff (1911-2009) holland orvos úttörő kísérletet végzett és kidolgozta a müvese alapjait a hemodialízis területén. Munkásságát több mint 12 
Kaleido scope
Journal of History of Culture, Science and Medicine

DOI: $10.17107 / \mathrm{KH} .2021 .22 .496-505$

díszdoktori címmel, és több mint 120 nemzetközi díjjal ismerték el. 1971-ben megkapta az American Academy of Achievement Golden Plate díját. ${ }^{1}$

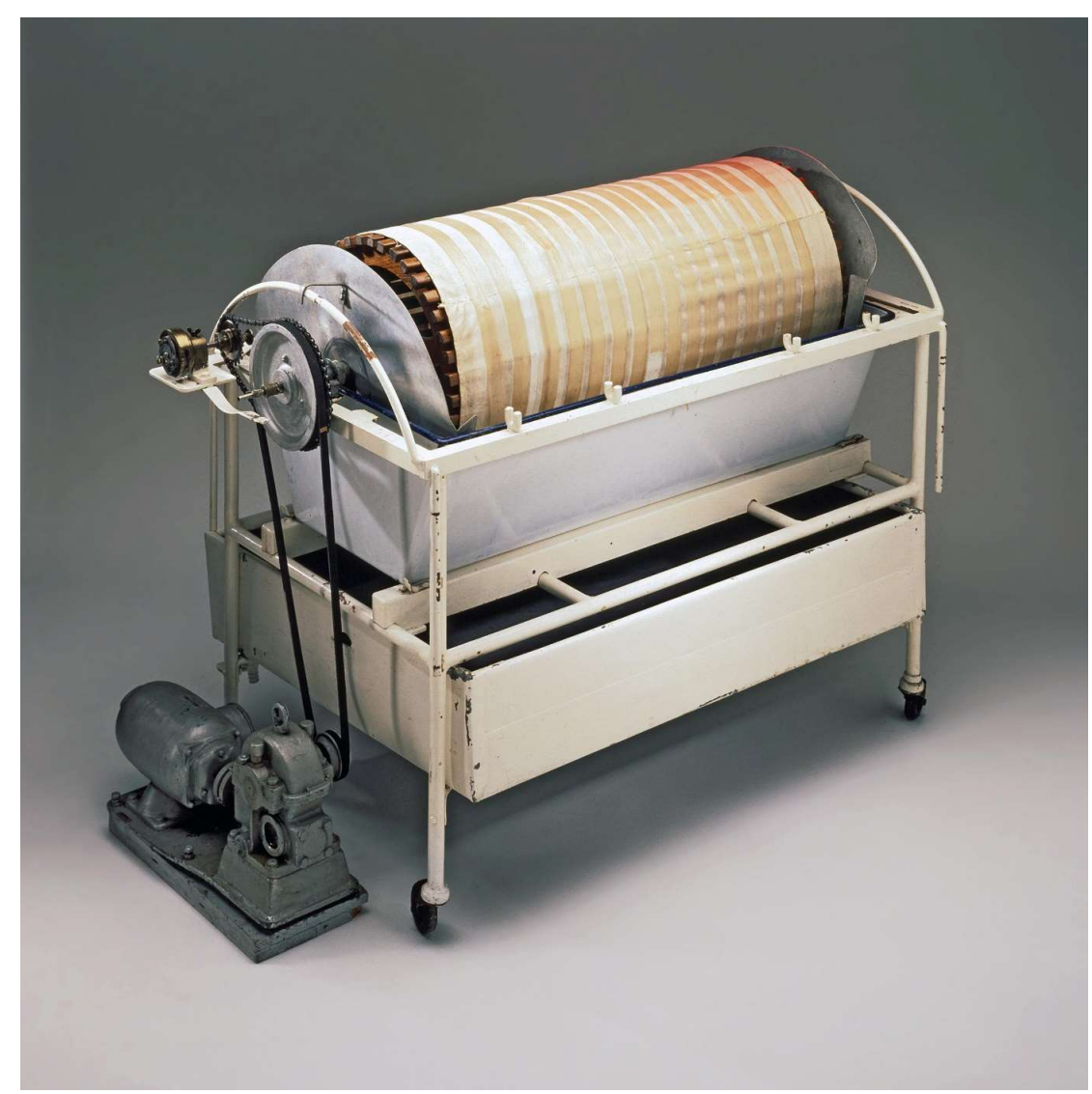

1. ábra: A Kolff-féle müvese (kép forrása: https://achievement.org/achiever/willem-j-kolff/ Letöltve: 2021. 04. 10.)

A Kolff-féle művese klinikai alkalmazását Nils Alwall (1904-1986), a Svéd Nefrológus Társaság alapítója és elnöke tette lehetővé. Nyulakon végzett kísérletes vizsgálatok után 1946 szeptemberében tekercsdializátorral végzett kezelést, mellyel a felesleges folyadékot eltávolította (Alwall, 1947). Leonard Tucker Skeggs (1918-2002) és Jack Leonards (1919-1978) amerikai kutatók nevéhez füződik az első klinikai kémiai analizátor, a lapdializátor (1948). A szerkezet kialakításának köszönhetően egyidejüleg kevesebb vér is elegendő volt a dializátorban. Biztosította a vér egyenletes eloszlását a membránon a nagyobb hatékonyság érdekében. A készülék gyártása sok időt vett igénybe, az eszközt 1956-ban mutatták be.

A magyarországi vizsgálatok a spanyol Bartrina féle (1952) szakaszos kezelést biztosító, kis hatásfokú dializátorral kezdődtek. Ezek eredményeit Mándi és Matolcsi, valamint Palócz és Sós az 50-es évek közepén adták közre. Gál György (1922-2016) Alwall-féle müvese készülékkel szerzett tapasztalatai alapján kifejlesztették a „Szeged” müvesét. Az első hazai müveseállomást Szegeden (1953) alapították, ahol az Alwall-féle készülék továbbfejlesztett változatával 1958-69 között több mint 400 dialízist végeztek. A budapesti Urológiai Klinika 1959 őszén kapott egy Necker típusú gépet. Az első hemodialízist 1960-ban végezték a fővárosi klinikán. Pécsen a dialízist Skeggs és Leonards lapdializátorának módosított változatával valósította meg Balogh Ferenc professzor és Pintér József adjunktus 1964-ben októberében.

\footnotetext{
${ }^{1}$ https://achievement.org/our-history/golden-plate-awards/\#science-exploration (2021. 04. 10.) 
Kaleidoscope

Debrecen Belgyógyászati Klinikáján 1970 őszén Kakuk György (1938-2018) és kollégái NDK gyártmányú készülékkel kezdték el a kezeléseket. Az egyetem müszaki dolgozói a Kenézy villa parkjában alakítottak át egy épületet, mely a müveseállomás helyszínét adta. Az ezt követő időszakban jelentős fejlődés mutatkozott. 1970 és 1990 között 24 új műveseállomást telepítettek ki hazánkban. A nefrológiai osztályok kialakításában és a szakképzés fejlesztésében kiemelkedő szerepe volt Taraba István professzor (1936-1990) munkásságának. (Karátson és mtsai, 2018).

A kezelés másik módja a hasi dialízis, melynek első hazai tapasztalatairól 1980-ban publikált Karátson és munkatársai. Az ezredfordulóra jelentősen megnőtt az így kezelt betegek száma, és a korszerü technikai lehetőségek által a peritonealis dialízissel kezeltek túlélése eléri, életminősége pedig meghaladta a hemodializált betegekét. A peritonealis és hemodialízissel kezeltek túlélését számos klinikai tanulmányban összehasonlították. Huang, Cheng és Wu (2008) vizsgálata szerint a hemodializáltak ötéves túlélési rátája 54\%, míg a peritonealis dializáltaké 56\%. Ugyanez tízéves távlatban 34\%-ra (HD) és 35\%-ra (PD) csökken, melyet jelentős mértékben befolyásol a diabétesz megléte és az idős életkor. Kolumbiai kutatók hasonló eredményre jutottak: a betegek túlélésében jelentős különbséget nem találtak (Sanabria és mtsai, 2008). Korábbi hazai felmérésünk során összehasonlítottuk a vesebetegek életminőségét a kezelési típus szerint létrehozott csoportok mentén. Az életminőség alskálái közül a Tünetek, a Foglalkoztatottság, a Kezelőszemélyzettől kapott támogatás és a Betegelégedettség esetében szignifikánsan magasabb pontszámot kaptunk a peritonealis dialíziskezelt betegek javára (Mátyás, Hargitai, Haris, megj. alatt). Az orvos-beteg szoros együttmüködésével végzett krónikus peritonealis dialízis nagyobb önállóságot és függetlenséget biztosít a végstádiumú vesebetegek számára, viszont nagyfokú szabálykövetést és jelentős odafigyelést igényel a beteg részéröl, hiszen a szigorú diétán és folyadékkorlátozáson túl többek közt higiéniai előírások betartására és az önkezelés pontos lépéseire is figyelniük kell (Szöllősy, 1997).

A krónikus vesebetegség magas előfordulása, a kezelésének magas költsége és az egyenlőtlen kezelhetőség miatt az etikai megfontolások szerves részét képezik a nefrológia történetének. A múlt század közepén Seattleben egy szakmai bizottság (melynek tagjai a publikum számára titkosak) segítségével választották ki azokat az orvosilag alkalmas végstádiumú vesebetegeket, akiket az ott létrehozott központ kezelt (Blagg, 1998). A krónikus dialízis korai szakaszában a kezelés olyan korlátozott mértékben volt csupán elérhető, hogy ez a bizottság volt hivatott eldönteni, mely betegek kapnak lehetőséget és ezáltal reményt az élethez.

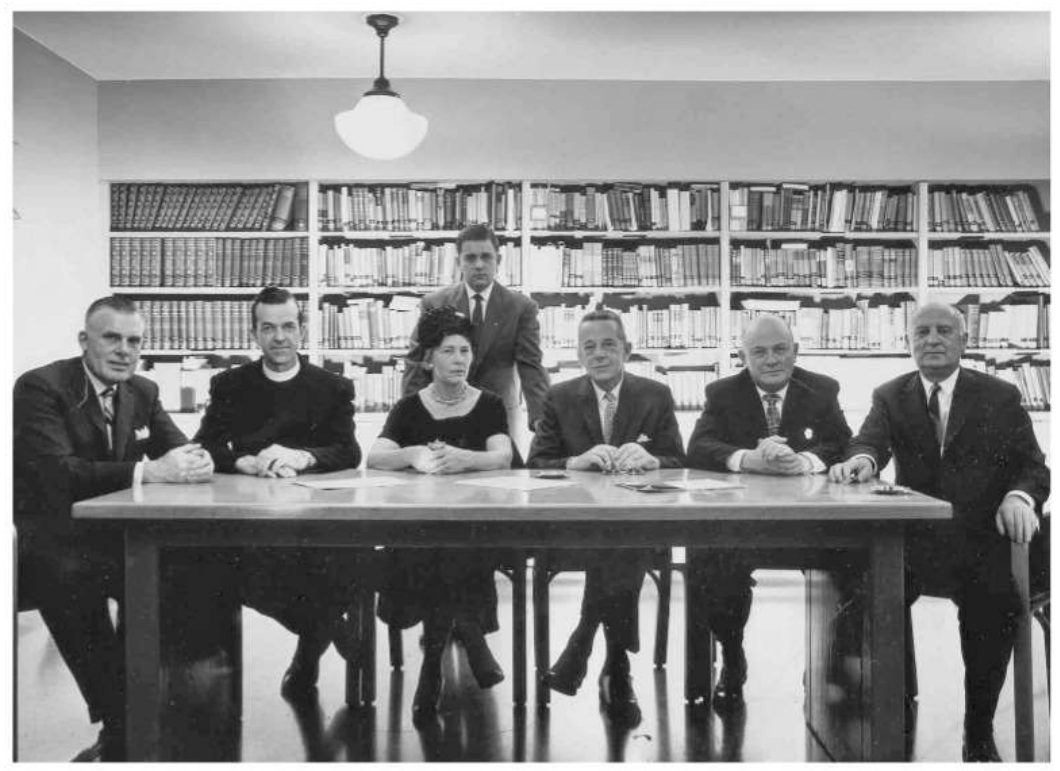

http://www.kaleidoscopehistory.hu Mátyás Eszter doktorandusz 
Kaleidoscope

2. ábra: Az ún. „Isten Bizottsága”, amely eldöntötte ki férhet hozzá a dialíziskezeléshez. (Kép forrása: http://danschmidtforsenate.com/blog/?p=291 Letöltve: 2021. 04. 03.)

A dialízisellátás privatizációjának és a 90-es évek elején felgyorsult fejlődésének eredményeként a fejlett országok szintjéhez közelítve, ma Magyaroroszágon gyakorlatilag minden beteg dialízisellátásban részesül, akinek szüksége van rá. Jelenleg hazánkban közel hatvan nephrologiai - dializáló osztály biztosítja a krónikus vesebetegek ellátását.

\section{Pszichoszociális tényezők szerepe}

A medicina egyik nagy útvesztője az egyoldalú biológiai és technikai orientáltság, mellyel szemben háttérbe szorulnak a páciens életterét alkotó szociológiai és a pszichológiai tényezők, mint kontextuális elemek. A modern orvoslás bio-pszicho-szociális elmélete értelmében (Engel, 1977) az egészségességet az élettani, a pszichológiai és a szociális rendszer kölcsönhatása alakítja. E szemlélet szerint az egészséget a bio-pszicho-szociális hatások egyensúlyi állapota jelenti. Krónikus megbetegedésekben ez a komplex egység megbomlik. A betegség krízisállapotot eredményez, amelyben a személy testi funkciói és fizikai szerepei megváltoznak, ily módon a páciens betegsége az életét és életminőségét teljesen átalakítja (Hajduska, 2008). Az egészségügyi ellátórendszerek a növekvő terhek megfékezéséért küzdenek, azonban azok nagymértékben a betegekre és az egészségügyi személyzetre hárulnak. Az orvosi ellátás és a betegek önirányítottságát fokozó programok segíthetik az egyéneket abban, hogy megértsék, mit kell tenniük az egészségük megőrzéséért, vagy a meglévő állapotuk fenntartásáért - illetve az állapotuk romlásának elkerülésére. A betegek mégis gyakran érzik úgy, hogy magukra lettek hagyva abban, hogyan változtassanak a viselkedésükön, milyen komplex életmódbeli szokások átalakítása és fenntartása szükséges a betegség kedvezőbb kimenetele szempontjából. Ily módon az önkezelés elengedhetetlen részévé válik a betegséggel való együttélésnek. A szelf-menedzsment alapja az, hogy a betegek aktív részesei legyenek egyéni terápiájuknak. Önmaguk elsődleges gondozóinak tekinthetők, arra alapozva, hogy a saját helyzetükről ők rendelkeznek a legtöbb tudással. Az egészségügyi gondozók feladata pedig abból áll, hogy segítsék a pácienseket ezen öngondozói szerepük megélésében oly módon, hogy megosztják a betegséggel kapcsolatos szakértői tudásukat, így a betegek kellő információ birtokába kerülnek a döntéseik meghozatalához (Bodenheimer, Lorig, Holman és Grumback, 2002).

\section{A kortárs fogalmának értelmezése}

A nemzetközi szakirodalomban a kortárs segítésnek nincs egységes, mindenki által elfogadott definíciója (Lukács és mtsai, 2018). A kortárs segítés ,,azonos vagy hasonló korcsoportba tartozó személyek (általában fiatalok) közt megvalósuló segítés és támogatásnyújtás illetve a másik személyre irányuló aktív figyelem" (D’Andrea és Salovey, 1983 idézi Rácz és Szabó, 2008. 11.o.). Egy másik definíció szerint a kortárs segítés az aktív figyelem és a problémamegoldó készségek használata, melyhez az emberi fejlődéssel és mentális egészséggel kapcsolatos ismeretek adódnak, annak érdekében, hogy konzultáljanak olyan társaikkal, akik hasonlóak életkorban, státuszban vagy tudásban. (D’Andrea és Salovey, 1983).

A magyar nyelvü szakirodalomban nehezíti, sőt teljesen félreviheti az értelmezést az is, hogy az angol „peer” kifejezés magyarul elterjedt fordítása, a „kortárs” túlságosan leegyszerüsítő. Szerencsésebb lenne a sorstárs, vagy a betegtárs kifejezés használata ebben az esetben. A magyar kortárs megnevezés nem követi az eredeti ,,peer” kifejezés tágabb jelentéstartalmát, életkorra szükíti le kapcsolódáshoz szükséges azonossági kritériumokat. Ezzel szemben az angolszász irodalom a valamivel vagy valakivel történő azonosságot nemre, társadalmi státuszra, etnikumra vagy valamilyen társadalmi csoportra, szubkultúrára egyaránt kiterjeszti (Turner és Shepherd, 1999). A kifejezés modern értelmezése alapján „peer” az a személy, aki vagy egyidős, vagy hasonló társadalmi helyzettel, hasonló képességekkel rendelkezik, mint az adott csoport többi tagja. Eszerint nem szükséges, hogy az egymást támogató betegek „kortársak” 
Kaleidoscope

(egykorúak) legyenek. A sorstárs segítő megnevezésből egyértelmüen kiderülne, hogy egy többnyire veszélyeztetett, vagy nehezen elérhető közösségi tagság is társul a segítő személyéhez. Jelen esetben tehát az, hogy a krónikus vesebetegségük következtében hasonló tapasztalatokkal rendelkeznek és azonos nehézségekkel szembesülnek a mindennapokban, melyekre közös erővel kereshetnek megoldásokat. Ám a továbbiakban maradtunk a kortárs kifejezésnél.

\section{Kortárstámogató programok kezdetei}

Clifford Whittingham Beers 1908-as A Mind That Found Itself címü könyvében elmekórházban töltött éveinek tapasztalatairól ír, melynek hatására kialakult Amerikában egy mentálhigiéné mozgalom. Célja az volt, hogy lehetőség szerint minél kevesebb ember betegedjen meg elmebetegségben, így elkerülhessék a kórházi ellátás szükségességét. Mozgalmak szerveződtek az alkoholizmus és drogfogyasztás ellen, valamint erkölcsi mozgalom indult a nemi úton terjedő betegségekkel szemben. A mentálhigiéné mozgalom a második világháborúig nagyon eredményes volt Európában. Az elmebetegséget és fogyatékosságot ekkor még örökletes betegségnek tartották - ezt az elméletet használta fel a náci ideológia. A betegségek átörökítésének megakadályozására kezdetben sterilizálták, majd később megölték az érintett embereket. A mentálhigiéné ezen értelmezése miatt megszünt a mozgalom, korábbi szocialista országokban a mentálhigiéné tiltott fogalommá vált. Magyarországon jelentősen növekedett a deviancia, melynek okát az ország lakosainak megromlott lelki egészségi állapotában látták. Az 1970-es években szerveződtek újra közösségi terápiák, támogató csoportok, ahol hasonló nehézségekkel küzdő emberek nyújthatnak segítséget társaiknak. Erre az időszakra tehetők az első mentálhigiéné programok, melyekbe sokféle civil szervezet is bekapcsolódott (Bagdy, 1996).

A társas támogatás szerepe a mentális betegségeken felül egyéb alkalmazási területeken is megnőtt, jelentőségét régóta vizsgálják. Kutatások bizonyítják, hogy a támogató közegek a mentális (Brown és Harris, 1978) és a testi betegségek (Newman, Steed és Mulligan, 2009) esetén is hozzájárulnak a hatékony önkezeléshez. Bizonyos krónikus betegségek kezelésében (cukorbetegség, szívbetegségek, pszichiátriai kórképek, daganatos megbetegedések, asztma), a prevenció hangsúlyozásában (AIDS, fertőző betegségek), valamint az anya-gyermek közötti egészséges kapcsolat kialakításában (szoptatás, táplálás, szülés utáni depresszió) a társas támogatói rendszerek jelentős szerepet kaptak. Ezzel szemben a közelmúltig kevés olyan program került kidolgozásra, amely támogatná a betegeket a szelf-menedzsment kialakításában. Amerikában - elsők között - krónikus ízületi gyulladásban szenvedő betegek önkezelésére irányuló egészségügyi programot dolgoztak ki (Lorig, Mazonson és Holman, 1993), az Egyesült Királyságban pedig diabétesszel diagnosztizált emberek számára hoztak létre csoportalapú támogatói programot (Davies és mtsai, 2008; Speight és mtsai, 2010). Miközben a végstádiumú vesebetegség és a különböző vesemüködést pótló kezelések hatalmas pszichés terhet jelentenek és jelentősen befolyásolják a páciensek szociális életét, az öket támogató mentorrendszerek - a fent említett betegcsoportokéhoz képest - csak évekkel később jelentek meg. A National Kidney Fundation 2012-ben indítja el a vesebetegek kortárs támogató programját.

\section{A társas támogatás szerepe krónikus vesebetegségben}

Végstádiumú vesebetegség esetén a kezelés rendkívül időigényes. Így a terápia hatására megváltozik a betegek munkahelyi, családi szerepük, aktivitásuk, a kezelések korlátozzák az utazásra, társasági életre való képességüket is (Patel, Peterson, Kimmel, 2005). Visszautalnék a cikk elején olvasható idézetre: ,, Sokat vagyunk együtt, mégis elpusztít minket a társas magány." Egy hemodializált beteg hetente legalább háromszor négy órát tölt a dialízisközpontban, betegtársai körében. Mégis, a kutatások eredményei szerint a végstádiumú vesebetegek körében igen gyakori probléma a megfelelő mértékủ szociális támogatás hiánya (Wuerth, Finkelstein, Ciarcia, Peterson, Kliger és Finkelstein, 2001). A társas támogatás mértéke azt adja meg, hogy a beteget körülvevő szociális háló, ahonnan figyelmet, törődést és segítséget kaphat, mennyire kiterjedt, milyen széles (House, Landis és Umberson, 1988). A támogató viselkedés változatos formákban nyilvánulhat meg: a szeretet, az értékelés, valamint a gondoskodás kimutatásában, de akár a segítő 
információk és gyakorlati segítség nyújtásában is. A szociális támogatás pozitívan hat a pszichológiai jóllétre és megakadályozza az egészség romlását, különösen a nehéz élethelyzetekben (Cohen, Underwood és Gottlieb, 2000). Mindez azáltal valósul meg, hogy a társas támogatás elősegíti azt, hogy a beteg megértse a megoldandó problémákat, motiváltabb legyen a problémamegoldó cselekvésre, a leghatékonyabb megküzdési stratégiát alkalmazza, és csökkentse a beteg akadályként jelentkező distressz mértékét. Ez a fajta támogatás hozzájárul a kedvező egészségmagatartáshoz, melynek következtében enyhülnek a betegséggel járó tünetek, illetve a csökkent stressz az immunrendszer müködésére is serkentő hatással van (Taylor, 2007).

Számos kutatási eredmény alátámasztotta, hogy a társas kapcsolatok minősége markáns előrejelzője a krónikus betegségekhez való alkalmazkodásnak (Wills, Fegan, 2001). A betegséghez történő alkalmazkodási feladatok szükségessé teszik mások segítségét. A betegséggel járó fájdalom és korlátozottság miatt a betegeknek a gyakorlati és a lelki támogatásra is igényük van, így nélkülözhetetlenné válnak az elérhető és kielégítő emberi kapcsolatok. A házastárstól, családtagoktól, munkatársaktól, barátoktól kapott társas támogatás mértéke fontos tényezőnek bizonyult számos krónikus megbetegedésben élő csoportban a klinikai kimenetel szempontjából (Hemingway és Marmot, 1999).

Christensen, Wiebe, Smith és Turner (1994) dializált vesebetegeket követett nyomon. Eredményeik szerint a kisebb családi támogatásban részesülő vizsgálati személyek ötéves mortalitási aránya közel háromszor magasabb volt, mint a jó szociális hálóval bíró pácienseké.

Számos kutatás irányult a társas támogatás és a depressziós tünetek közötti összefüggések feltérképezésére. Lepore (2001) társas-kognitív modellje szerint az érzelmileg megterhelő élethelyzetekről történő támogató beszélgetés hozzájárul a nehéz szituációk feldolgozásához, segíti a pozitív énkép fenntartását, és a nehéz helyzetekben való értelemtalálást. Gencoz és Astan (2006) hemodializált vesebetegeket vizsgálva igazolta, hogy a szociális támogatás hiánya súlyosabb depressziós tünetek kialakulását eredményezte. Azok a vizsgálati személyek, akik elégedettebbek voltak a társas támogatás mértékével szignifikánsan kevesebb depresszióra utaló tünetet mutattak. Török kutatók peritoneális dialízissel kezelt betegek csoportján szintén fordított irányú kapcsolatot találtak a társas támogatás és a depresszió között (Asti, Kara, Ipek és Erci, 2006).

\section{Társas támogatáson alapuló programok}

Milburn (1995) szerint a kortárssegítés, mint tudás-, magatartás-, és értékközvetítő módszer egyszerű és kézzelfogható sajátosságai miatt - informálisan ugyan - mindig jelen volt. Szerinte a szexuális egészségfejlesztés a fiatalok között úgy valósul meg, hogy információkat osztanak meg egymással, amelyeket különféle forrásokból - beleértve saját, személyes tapasztalataikat is - szereztek meg. Így a kortársak szerepe szexuális nevelés szempontjából is jelentős.

Az 1960-as és 1970-es években sok szociálpszichológiai kutatás zajlott a kortársakról, mint modellekröl. A kortárstámogatás hatékonysága és müködési mechanizmusa számos tudományos elmélettel is alátámasztható. Az egyik kiemelkedő magyarázat Albert Bandura nevéhez kötődik. A szociális tanuláselmélet (Bandura, 1977) szerint a modellezés fontos eleme a tanulási folyamatnak, hiszen az alanyok megfigyelés után adoptálják az adott viselkedésmintát, melyhez nélkülözhetetlen a modell hitelessége és a tanult viselkedés megerősítése. A társadalmilag tanult viselkedésminta alkalmazása azáltal lesz valószínűbb, hogy az ember bízik abban, hogy a bizonyos viselkedésminta elhozza számára a sikert.

A kortárs támogatás sikerességét magyarázó elméletek közül szintén kiemelkedő Everett Rogers innováció diffúziójáról szóló nézete. Ez alapján az innováció, vagyis a kortársoktatás tartalmának terjedését, sikerességét több tényezö határozza meg. Ebböl kifolyólag különös hatékonysággal müködnek azok a programok, ahol a résztvevők hasonló jellemzőkkel rendelkeznek: jelen esetben a mentorok és mentoráltak egyazon betegségben érintettek, hasonló korosztályból kerülnek ki, stb. Elméletének további fontos aspektusa, hogy a kortársoktató a mentoráltjához képest magasabb tudásbeli pozíciót töltsön be, ezzel a 
program hatékonysága fokozható (Rogers, 1983). Ez azzal érhető el, hogy a mentor szerepében lévő beteg példaértéküen küzd meg a betegségével, eredményessége az orvosi értékeiben is tetten érhető, mentorrá válásához pedig egy képzésben kell reszt vennie.

A támogató kapcsolat létrejöttével a bizalom két párhuzamos mechanizmusból fakad. Egyrészről a mentor mintát nyújt, vagyis példaképként szolgál az általa támogatott betegek számára, így arra ösztönzi őket, hogy hatékonyabban menedzseljék saját betegségüket és javítsák a társas müködésüket. Másrészről pedig a mentor és mentoráltja közötti kapcsolat erősödése hídként szolgál a beteg és a többi mentorprogramon kívüli - egészségügyi dolgozó között. A beteg mentorába fektetett bizalma kiterjeszthető a gondozó csapat többi tagjára is, ami lehetővé teszi a páciens számára, hogy legyőzze a megbélyegződéstől való félelmét. Ebben a szerepben a kortárssegítő megkönnyíti a betegnek a közösséggel való kapcsolatát, így bátrabban meri feltenni személyes, vagy akár korábban kínosnak gondolt kérdéseit (Gillard és mtsai, 2015). A fent említett eredmények tükrében látható a szociális támogatás hatékonysága, így érthető, hogy az az egészségügy területén egyre nagyobb elismerést élvez. Az internet globális elterjedtsége, valamint a közösségi média és a közösségi hálózatok növekedése megkönnyítette a társak támogatásának elérhetőségét és alkalmazását.

A Peer for Progress az American Academy of Family Physicians által 2006-ban kezdeményezett, jelenleg az Észak-Karolinai Egyetemen müködő program, mely a kortárstámogatással foglalkozó kutatók, szakértők és mentorok nemzetközi hálózatát jelenti. Ez a kortárstámogató program a krónikus betegséggel élő embereket kapcsolja össze az ismeretek és tapasztalatok megosztása érdekében. A Peers for Progress szerint a kortárstámogatás gyakori, folyamatos, hozzáférhető és rugalmas segítségnyújtás, mely számos formában megvalósulhat: a telefonhívásoktól és szöveges üzenetektől kezdve a csoportos online beszélgetéseket át, a személyes találkozókig és otthoni látogatásokig (Boothroyd és Fisher, 2010).

A program megalkotói szerint a kortárstámogatásnak négy alapvető funkciója van:

1. segítség a betegség okozta mindennapos nehézségek leküzdésében, megoldásában saját tapasztalataik megosztásával

2. szociális és érzelmi támogatás nyújtása (bátorítás, motiváció fenntartása, empatikus hallgatás)

3. információnyújtás, szükség esetén kapcsolatteremtés a klinikai ellátással

4. hosszútávú nyomon követéssel a beteg elkötelezödése elérhető

\section{Jövőbeli tervek a hazai mentorprogram kialakítására}

Látható tehát, hogy ahhoz, hogy egy krónikus beteg alkalmazkodni tudjon a betegsége okozta nehézségekhez, érzelmi támogatásra és oktatásra van szüksége. A mai világban ezen igények kielégítése mind a beteg, mind a klinikus számára egyaránt kihívást jelentenek. A páciensek gyakran nyomtatott anyagokat kapnak, amelyek megkönnyítik a betegség megismerését és az ahhoz való alkalmazkodást. Sok betegnél azonban a szóbeli tanácsadás sokkal hatékonyabb lehet, mint a nyomtatott anyag. Amerikai betegek hasznosnak találták a betegtársakkal való beszélgetést. Javaslatot tettek egy hivatalos támogató rendszer létrehozására, amelyben a kezelés megkezdése előtt álló betegek beszélhetnek másokkal, akiknek már tapasztalata van a dialíziskezelésben.

A National Kidney Foundation (2009) kidolgozott egy telefonos rendszert, amelyben a támogatást igénylő vesebetegek segítséget kaphatnak egy olyan mentortól, aki betegtársként példaértékün küzd meg a vesebetegségével. A tanulmányok azt mutatják, hogy az egymástól kapott támogatás hatékony a hosszú távú dialíziskezelés terápiájában, hiszen csökkenti az elszigeteltség és megbélyegzés érzését, enyhíti a félelmeket és válaszokat szolgáltat az esetleges kérdésekre, különösen akkor, ha a beteget újonnan diagnosztizálták, vagy nehézségekbe ütközik a betegség kezelésében (Hughes, Wood és Smith, 2009). A kortárstámogatás azért müködik, mert a betegek olyasvalamit képesek adni egymásnak azáltal, hogy hasonló kihívásokkal szembesülnek, amit a klinikusok nem: osztoznak az átélt, valós tapasztalatokban. Fontos a sorstársi kapocs, hiszen sok ember számára könnyebb megbeszélni egy problémát vagy aggodalmat hasonló háttérrel 
rendelkező és azonos egészségügyi problémával élő személlyel. A kutatások azt mutatják, hogy a másoknak nyújtott szociális támogatás javíthatja a segítő egészségét is. Azok a személyek, akik másoknak segítenek, tájékozottabbá válnak és magabiztosabbak képességeikben (Brunier, Graydon, Rothman, Sherman és Liadsky, 2002). A kortárs kapcsolat irányítását és szakmai felügyeletét végzi a National Kidney Foundation szakértő klinikusa. A mentorok előzetesen egy átfogó képzésben vesznek részt, mely biztosítja ismereteik szakmai hitelességét. Ezt követően válnak a segítő rendszer tagjaivá. Önkéntes szolgáltatásukkal empátiát és megértést tanúsítanak betegtársaik felé. Megerősítik a segítséget kérőket őket abban, hogy nincsenek egyedül, orvosi kérdésekkel pedig az egészségügyi teamhez irányítják a beteget. A telefonos szolgáltatás ingyenes. Előnyei között szerepel, hogy anonimitást és adatvédelmet biztosít a résztvevők számára, akiknek ezáltal könnyebb megnyílni és őszintének lenni. Továbbá megszünteti a távolságból fakadó akadályokat és lehetővé teszi a gyakori kapcsolatfelvételt alacsony költség mellett. A program az önkéntes kortárssegítő számára is hasznos, hiszen az énhatékonysága fokozódik, az önértékelése nő és a hatékony segítségnyújtás által megélheti az aktív, cselekvő szerepkörét. Így a rendszer bevezetésével együttjáró erőfeszítések minden bizonnyal megtérülnének. Jelen tudásunk szerint Magyarországon nincs müködésben kortárs támogató rendszer vesebetegek számára. Korábbi kutatásunk (Mátyás, Hargitai és Haris, megj. alatt) eredményei azonban indokolttá teszik, hogy az alacsonyabb egészségmüveltséggel rendelkező hemodializált betegekre fókuszálva egy - az amerikai programhoz hasonló - protokoll kerüljön kidolgozásra, amelyben a tapasztalt betegtársak nyújthatnak szupportív jellegü információt és támaszt a többi kezelt betegnek.

Ez egy reális és megvalósítható törekvés lehet a közeljövőben hazánkban is, amely úgy növelheti a dializált betegek életminőségét, hogy közben az amúgy is túlterhelt egészségügyi személyzetre nem rovunk plusz terhet.

\section{Irodalom}

AlWALl, N. (1947). On the artificial kidney I. Apparatus for dialysis of the blood in vivo. Acta Med Scand;128:317-25. https://doi.org/10.1111/j.0954-6820.1947.tb06601.X

ASTI, T., KARA, M., IPEK, G., ERCI, B. (2006). The experiences of loneliness, depression, and social support of Turkish patients with continuous ambulatory peritoneal dialysis and their caregivers. J Clin Nurs 15:4907. https://doi.org/10.1111/j.1365-2702.2006.01330.x

BAGDY, E. (1996). A mentálhigiéné főbb irányzatai és a hazai Mentálhigiénés Program, in: Mentálhigiéné,elmélet, gyakorlat, képzés, kutatás, Animula, Budapest

BlagG, C. (1998). Development of ethical concepts in dialysis: Seattle in the 1960s. Nephrology, 4. https://doi.org/10.1111/j.1440-1797.1998.tb00353.x

BODENHEIMER, T., LORIG, K. R., HOLMAN, H., ÉS GRUMBACH, K. (2002). Patient selfmanagement of chronic disease in primary care. Journal of the American Medical Association, 288, 2469-2475. https://doi.org/10.1001/jama.288.19.2469

BoOTHROYD, R. I., \& FiSHER, E. B. (2010). Peers for progress: promoting peer support for health around the world. Family practice, 27(suppl_1), i62-i68. https://doi.org/10.1093/fampra/cmq017

Brown, G. W., \& HARrIS, T. (1978). Social origins of depression: a reply. Psychological medicine, 8(4), 577-588. https://doi.org/10.1017/S0033291700018791

BRUNIER G, GRAYDON J, ROTHMAN B, SHERMAN C, LIADSKY R. (2002). The psychological well-being of renal peer support volunteers. J Adv Nurs.;38(1):40-49. https://doi.org/10.1046/j.1365-2648.2002.02144.X Christensen, A. J., Wiebe, J. S., Smith, T. W., Turner, C. W. (1994). Predictors of survival among hemodialysis patients: effect of perceived family support. Health Psychol 13:521-5 https://doi.org/10.1037/0278-6133.13.6.521

ClifFORD, W. B. (1908). A Mind That Found Itself, An Autobiographie, Longman, Green, and Co, New York 
Cohen, S., Underwood, L. G., Gottlieb, B. H. (Eds.). (2000). Social support measurement and intervention. New York, Oxford University https://doi.org/10.1093/med:psych/9780195126709.001.0001

Davies, M. J., Heller, S., Skinner, T. C., Campbell, M. J., Carey, M. E., Cradock, S., ... \& Khunti, K. (2008). Effectiveness of the diabetes education and self management for ongoing and newly diagnosed (DESMOND) programme for people with newly diagnosed type 2 diabetes: cluster randomised controlled trial. Bmj, 336(7642), 491-495. https://doi.org/10.1136/bmj.39474.922025.BE

Engel, G. L. (1977). The Need for a New Medical Model: A Challenge for Biomedicine. Science, 196(4286): 129-136. https://doi.org/10.1126/science.847460

Gencoz, T., Astan, G. (2006). Social support, locus of control, and depressive symptoms in hemodialysis patients. Scand J Psychol 47:203-8 https://doi.org/10.1111/j.1467-9450.2006.00508.x

Gillard, S., GiBSON, S., Holley, J., \& LUCOCK, M. (2015). Developing a change model for peer worker interventions in mental health services: A qualitative research study. Epidemiology and Psychiatric Sciences, 24(5), 435-445. https://doi.org/10.1017/S2045796014000407

HAAS, G. (1928). Über Blutwaschung. Klin Wschr 1928;7:1356-62 https://doi.org/10.1007/BF01749240 HAJDUSKA, M. (2008). Krizislélektan, pp 9-30, 151-164, ELTE Eötvös Kiadó

Hemingway, H., MARMot, M. (1999). Evidence based cardiology: psychosocial factors in the aetiology and prognosis of coronary heart disease. Systematic review of prospective cohort studies. Bmj 318:1460-7 https://doi.org/10.1136/bmj.318.7196.1460

House, J. S., LANDis, K. R., UMBERSON, D. (1988). Social relationships and health. Science 241:540-5 https://doi.org/10.1126/science.3399889

HuAng, C. C., Cheng, K. F., \& Wu, H. D. I. (2008). Survival analysis: comparing peritoneal dialysis and hemodialysis in Taiwan. Peritoneal Dialysis International, 28(3_suppl), 15-20. https://doi.org/10.1177/089686080802803s04

Hughes J, Wood E, Smith G. (2009). Exploring kidney patients' experiences of receiving individual peer support. Health Expect.;12(4):396-406. https://doi.org/10.1111/j.1369-7625.2009.00568.x

KARÁtSON, A., Jung, N., Thieler, H., BAufeld, H., SCHMIDT, U. (1980). Laborkémiai értékek változása folyamatos peritonealis dializis hatására, Orvosi Hetilap, 121:2633-34

KARÁTSON, A., KAKUK, GY., MAKÓ, J., KISS, É., ZAKAR, G. (2018). A hazai hemodialízis kezdete a múlt század második felében. Hypertonia és Nephrologia, 22(05), 229-236.

LEPORE, S. J. (2001). A social-cognitive processing model of emotional adjustment to cancer. In Baum, A., Andersen, B. L. (Eds.): Psychosocial interventions for cancer. (pp. 99-116). Washington, DC, American Psychological Association. https://doi.org/10.1037/10402-006

LORIG, K. R., MAZONSON, P. D., \& Holman, H. R. (1993). Evidence suggesting that health education for self-management in patients with chronic arthritis has sustained health benefits while reducing health care costs. Arthritis \& Rheumatism: Official Journal of the American College of Rheumatology, 36(4), 439-446. https://doi.org/10.1002/art.1780360403

LUKÁCS, J. Á., MÉSZÁROSNÉ, D. S., SoÓSNÉ, K. ZS. ET AL. (2018). Kortárs egészségfejlesztési programok gyermekek és fiatalok körében a hazai és a nemzetközi szakirodalom tükrében - Szisztematikus áttekintés. Egészségfejlesztés, 59, 1, 6-24. https://doi.org/10.24365/ef.v59i1.215

MÁtyÁs, E., Hargitai, R., HARIs, Á. (megj. alatt). Dializált betegek életviteli nehézségeinek megismerése kvantitatív vizsgáló módszerekkel, Orvosi Hetilap, (Közlésre elfogadva, megjelenés előtt)

Milburn, K. (1995): A Critical Review of Peer Education with Young People with Special Reference to Sexual Health. Health Education Research, 10, 4, 407-442. https://doi.org/10.1093/her/10.4.407

Newman, S., Steed, E., \& Mulligan, K. (2008). Chronic physical illness: self-management and behavioural interventions: self management and behavioural interventions. McGraw-Hill Education (UK). 
Kaleidoscope Müvelödés-, Tudomány- és Orvostörténeti Folyóirat Journal of History of Culture, Science and Medicine
2021. Vol. 11. No. 22.

ISSN 2062-2597

DOI: $10.17107 /$ KH.2021.22.496-505

PATEL, S.S., PETERSON, R. A., KiMMEL, P. L.(2005). The impact of social support on end-stage renal disease. Semin Dial 18:98-102 https://doi.org/10.1111/j.1525-139X.2005.18203.x

RÁCZ, J. SzABÓ, G. (2008). A kortárs és sorstárs segítés módszere. In: Rácz, J. (szerk.): Az esélyteremtés új útjai: kortárs és sorstárs segítéssel szerzett tapasztalataink. L’Harmattan kiadó, Budapest. 12-52.

Rogers, E. M. (1983): Diffusion of Innovations. $3^{\text {rd }}$ ed. New York: Free Press

SkEGgS, E.T., LeONARDS, J.R. (1948). Studies on an artificial kidney. Preliminary results with a new type of continous dialyzer. Science;10:212-3. https://doi.org/10.1126/science.108.2800.212

Sanabria, M., Munoz, J., Trillos, C., Hernandez, G., Latorre, C., Díaz, C. S., ... \& Vargas, E. (2008). Dialysis outcomes in Colombia (DOC) study: a comparison of patient survival on peritoneal dialysis vs hemodialysis in Colombia. Kidney International, 73, S165-S172. https://doi.org/10.1038/sj.ki.5002619

Speight, J., Amiel, S. A., Bradley, C., Heller, S., Oliver, L., Roberts, S., ... \& Thompson, G. (2010). Long-term biomedical and psychosocial outcomes following DAFNE (Dose Adjustment For Normal Eating) structured education to promote intensive insulin therapy in adults with sub-optimally controlled type 1 diabetes. Diabetes research and clinical practice, 89(1), 22-29. https://doi.org/10.1016/j.diabres.2010.03.017

SzÖLlŐSY, GY. (1997). A vesék anatómiája és müködése. In Makó, J., Szöllösy, Gy., Tanácsok vesebetegeknek: megelőzés, kezelés, gondozás, életmód, életminőség, életkilátások. Budapest, Springer Hungarica Kiadó

TAYLOR, Sh. E. (2007). Social support. In Friedman, H., S., Silver, R. C.: Foundations of Health Psychology. New York, Oxford University Press, 145-171.

TURNER, G., SHEPHERD, J. (1999). A Method in Search of a Theory: Peer Education and Health Promotion. Health Education Research, 14, 2, 235-247. https://doi.org/10.1093/her/14.2.235

Wills, T. A., Fegan, M. F., Baum, A., ReVenson, T. A., \& Singer, J. E. (2001). Handbook of health psychology.

Wuerth, D., Finkelstein, S. H., Ciarcia, J., Peterson, R., Kliger, A.S., Finkelstein, F. O. (2001). Identification and treatment of depression in a cohort of patients maintained on chronic peritoneal dialysis. Am J Kidney Dis 37:1011-7 https://doi.org/10.1016/S0272-6386(05)80018-6

Yach, D., Hawkes, C., Gould, C., Hofman, K. (2004). The global burden of chronic diseases: overcoming impediments to prevention and control, J Amer Med Assoc, 291, pp. 2616-2622 https://doi.org/10.1001/jama.291.21.2616 